\title{
Występowanie dolegliwości bólowych dolnego odcinka kręgosłupa i nawyków ruchowych u osób prowadzą- cych siedzący tryb życia
}

Sabina Kaczor ${ }^{1}$, Aneta Bac ${ }^{1}$, Paulina Brewczyńska1, Renata Woźniacka ${ }^{2}$ Edward Golec ${ }^{1,3}$

'Zakład Rehabilitacji w Ortopedii, Katedra Rehabilitacji Klinicznej, Akademia Wychowania Fizycznego im. Bronisława Czecha w Krakowie

'Zakład Anatomii, Katedra Fizjoterapii, Akademia Wychowania Fizycznego im. Bronisława Czecha w Krakowie

${ }^{3}$ Klinika Chirurgii Urazowej i Ortopedii 5. Wojskowego Szpitala Klinicznego z Polikliniką SPZOZ w Krakowie

\section{Streszczenie}

Obecnie dolegliwości bólowe kręgosłupa lędźwiowo-krzyżowego stanowią istotny problem zdrowotny, społeczny i ekonomiczny. Celem pracy była ocena dolegliwości bólowych dolnego odcinka kręgosłupa i nawyków ruchowych u osób prowadzących siedzący tryb życia, wynikający z charakteru wykonywanej pracy zawodowej.

Badania przeprowadzono w okresie od listopada 2010 do lutego 2011. Materiał badawczy stanowiły 2 grupy osób: 57 pracowników biurowych (w tym 40 kobiet i 17 mężczyzn) oraz 43 kierowców autobusów i taksówkarzy (wyłącznie mężczyźni). W pierwszej grupie przedział wiekowy mieścił się w granicach od 21 do 60 lat, a w drugiej między 21, a 63 lat. Narzędzie badawcze stanowiła autorska ankieta składająca się z czterech części. Pierwsza i druga część zawierała pytania dotyczące danych osobowych oraz informacji na temat wykonywanej pracy. W trzeciej zapytano o ewentualne dolegliwości bólowe dolnego odcinka kręgosłupa, natomiast w czwartej o nawyki ruchowe, znajomość profilaktyki i sposób spędzania czasu wolnego.

Uzyskane wyniki świadczą o częstszym występowaniu dolegliwości bólowych dolnego odcinka kręgosłupa wśród kierowców (62,8\%). Problem ten dotyczy również częściej osób z wysokim nieprawidłowym BMI (25 i powyżej). Więcej nieprawidłowości w postawie ciała pojawiało się w grupie pracowników biurowych niż wśród kierowców.

Prevalence of low back pain and motor habits in individuals leading a sedentary lifestyle

\section{Summary}

Currently, low back pain is a major health social and economic problem. The aim of this study was assessment of low back pain and habits of movement in individuals leading a sedentary lifestyle, due to the nature of their work.

The study was conducted from November 2010 to February 2011. Research material consisted of two groups of people: 57 office workers (including 40 women and 17 men) and 43 bus drivers and taxi drivers (men only). In the first group age ranged from 21 to 60 years, and the second between 21 and 63 years. Research tool was the author's own questionnaire consists of four parts. The first and second part contained questions about personal data and information about the job. In the third part respondents were asked about any pain in the lower spine, while in the fourth part we asked about movement of habits, knowledge of prevention and ways of spending free time.

The results indicate frequent occurrence of low back pain among drivers $(62,8 \%)$. This problem also often applies to people with high abnormal BMI (25 and above). More irregularities in posture appeared in the group of office workers than among drivers.

Słowa kluczowe:

postawa ciała, ból, kierowcy, pracownicy biurowi 


\section{Wstęp}

Zespoły bólowe kręgosłupa lędźwiowo-krzyżowego ze względu na ich rozpowszechnienie stanowią istotny problem zdrowotny współczesnych społeczeństw, szczególnie państw wysoko rozwiniętych. Szacuje się, że przynajmniej raz w życiu na dolegliwości bólowe dolnego odcinka kręgosłupa skarży się od $60 \%$ do $90 \%$ populacji. Zwykle pojawiają się one między 25-65 rokiem życia i w równym stopniu dotyczą obu płci. [1, 2, 3, 4, 5, 6, 7, 8]

Zjawisko to nie może być rozpatrywane jedynie w aspekcie medycznym. Koszty wynikające z rosnących wydatków na opiekę zdrowotną oraz nieobecności w pracy, czy też niezdolność do jej wykonywania sprawiają, iż znaczącą rolę odgrywa tu aspekt ekonomiczny. Szacuje się, że w Stanach Zjednoczonych wydatki związane z samym leczeniem bólów krzyża wynoszą ok.100 bilionów dolarów rocznie. [9, 5]

Uważa się, że gdyby świadomość społeczna w zakresie profilaktyki bólów kręgosłupa była większa, prawdopodobnie zjawisko to nie byłoby aż tak powszechne. W doniesieniach naukowych martwi fakt, że pomimo dostępności informacji, większość osób nie zna i/lub nie stosuje podstawowych zasad. Taki stan wymaga natychmiastowego podjęcia działań zmierzających do jego zmiany. [1, 10, 11, 12]

Specyficzny ból krzyża stwierdzany jest bardzo rzadko (ok.10\% przypadków). O wiele częściej występuje niespecyficzny ból krzyża, o nieznanym podłożu. Nie koreluje on ze zmianami strukturalnymi i zwykle charakteryzuje się korzystnym przebiegiem. U większości chorych dolegliwości zmniejszają się w ciągu kilku tygodni, a następnie mijają całkowicie. Tylko u niewielkiej grupy pacjentów (ok. 5\%) ostry epizod bólu krzyża przechodzi w stan przewlekły. Częste są natomiast jego nawroty. $[4,5]$

Z występowaniem niespecyficznego bólu krzyża wiązane są czynniki powodujące jego przeciążenie, takie jak mikrourazy, nadmierne obciążenie, niekorzystne kierunki sił oddziaływujące na kręgosłup podczas jego pracy oraz w spoczynku. Najczęściej są to oddziaływujące w długim okresie czasu, często występujące bodźce podprogowe, które sumując się prowadzą do uszkodzenia tkanek i ich osłabienia. [13, 14, 15]

\section{Cel pracy i pytania badawcze}

Celem niniejszej pracy była ocena dolegliwości bólowych dolnego odcinka kręgosłupa i nawyków ruchowych u osób prowadzących siedzący tryb życia.

1. W której z badanych grup dolegliwości bólowe dolnego odcinka kręgosłupa występowały częściej?

2. Czy w badanych grupach u osób z wysokim BMI (ponad normę) występowały dolegliwości bólowe kręgosłupa lędźwiowo-krzyżowego?

3. Które $z$ badanych nawyków ruchowych odznaczały się największym stopniem niepoprawności u badanych osób?

\section{Materiał badawczy}

Materiał badawczy stanowiło 100 osób (podzielonych na 2 grupy) prowadzących siedzący tryb życia, rozumianym jako długotrwałe utrzymywanie pozycji siedzącej, wynika- jącej z charakteru wykonywanego zawodu. Grupę pierwszą stanowili pracownicy biurowi (57 osób $=57 \%$ ), w drugiej znaleźli się kierowcy autobusów oraz taksówkarze (43 osób $=43 \%)$.

Wśród pracowników biurowych było 40 kobiet $(70,2 \%)$ oraz 17 mężczyzn $(29,8 \%)$ w wieku od 21 do 60 lat (średni wiek 40,2 lata). Masa ciała mieściła się w przedziale od 53 $\mathrm{kg}$ do $110 \mathrm{~kg}$ (średnia masa $=71,7 \mathrm{~kg}$ ), wzrost mieścił się $\mathrm{W}$ granicach od 1,5 $\mathrm{m}$ do 1,86 $\mathrm{m}$ ('średni wzrost $=1,69 \mathrm{~m}$ ).

W drugiej grupie (kierowców) znaleźli się sami mężczyźni (43 osoby). Wiek najmłodszego wynosił 21 lat, a najstarszego 63 lata (średni wiek = 42,6 lat). Masa ciała oscylowała w przedziale od $58 \mathrm{~kg}$ do $106 \mathrm{~kg}$ (średnia masa $=81,5 \mathrm{~kg}$ ), wzrost mieścił się $\mathrm{w}$ granicach od 1,58 $\mathrm{m}$ do $1,9 \mathrm{~m}$ (średni wzrost $=1,75 \mathrm{~m})$.

W całej grupie (100 osób) znalazło się 40 kobiet i 60 mężczyzn (40\% i 60\%). Średnia wieku była równa 41,43 lat(40,8 lat dla kobiet i 41,9 lat dla mężczyzn). Średnia masa ciała była równa $75,9 \mathrm{~kg}(67,1 \mathrm{~kg}$ dla kobiet i $81,8 \mathrm{~kg}$ dla mężczyzn), a średni wzrost wśród badanych wynosił $1,71 \mathrm{~m}$ (1,65 m dla kobiet i 1,75 m dla mężczyzn).

Wykształcenie wyższe w wśród wszystkich badanych posiadało $28 \%$ (odpowiednio $45,6 \%$ pracowników biurowych i 4,7\% kierowców), wyższe niepełne 9\% (14\% i 2,3\%), średnie $37 \%$ (40,4\% i 32,6\%), średnie niepełne $10 \%(0 \%$ i $23,3 \%$ ), a zawodowe $16 \%$ (0\% i 32,7\%). Jako miejsce zamieszkania 50\% wszystkich ankietowanych podało miasto powyżej 500 tysięcy mieszkańców, 1\% miasto od 100 do 500 tysięcy mieszkańców, $1 \%$ miasto od 25 do 50 tysięcy mieszkańców, 7\% miejscowość od 10 do 25 mieszkańców, a $47 \%$ wieś.

\section{Metoda badawcza}

Badania przeprowadzono w okresie od listopada 2010 do lutego 2011. Do ich wykonania posłużyła anonimowa, autorska ankieta składająca się z czterech części.

Część pierwsza zawierała pytania dotyczące płci, daty urodzenia (rok), miejsca zamieszkania oraz posiadanego wykształcenia, a także wzrostu i masy ciała, na podstawie których wyliczono BMI.

W części drugiej zapytano o charakter wykonywanego zawodu, staż pracy, ilość dni spędzanych w pracy w ciągu tygodnia, a także o ilość godzin spędzanych w pozycji siedzącej w pracy i poza praca,

Trzecia część zawierała 10 pytań dotyczących dolegliwości bólowych odcinka lędźwiowego kregosłupa, ich dotychczasowego leczenia, wpływu na pracę zawodową, zwolnień lekarskich oraz ewentualnych przyczyn dolegliwości. Jeśli na pierwsze pytanie na temat występowania bólów dolnego odcinka kręgosłupa ankietowany odpowiedział twierdząco, odpowiadał na pozostałe 9 , jeśli zaś negatywnie przechodził do czwartej części.

W ostatniej, czwartej części ankiety badany został zapytany o preferowany sposób spędzania wolnego czasu, a także o znajomość zasad profilaktyki dolegliwości bólowych kręgosłupa. Dalsze pytania w tej części dotyczyły sposobów wykonywania różnych czynności w ciagu dnia - siedzenia, wstawania z pozycji leżącej, stania, schylania się i podnosze- 
nia przedmiotów, noszenia, czynności związanych z higiena, sprzątania, ścielenia łóżka oraz ubierania. Zostały one przedstawione schematycznie, a ankietowany wybierał z podanych wariantów jeden, najczęściej przez niego stosowany.

\section{Wyniki}

\section{Statystyka opisowa}

Pierwszym analizowanym pytaniem ankietowym była długość stażu pracy. Wśród pracowników biurowych najmniej było osób o stażu pracy wynoszącym od 25 do 30 lat $(8,78 \%)$, a najwięcej tych pracujących od 5 do 10 lat i poniżej
5 lat (17,53\% i 17,53\%). W grupie kierowców większość stanowiły osoby, których staż pracy kształtował się w granicach 10-15 lat (20,94\%), najmniej pracowało od 20 do 25 lat.

Następnie zapytano o ilość dni spędzanych w pracy w ciągu tygodnia. Przeważająca część badanych (86\%) wykonywała swoją pracę 5 dni w tygodniu $(92,98 \%$ pracowników biurowych, 76,74\% kierowców). Pozostali pracowali 4 lub 6 razy w tygodniu (w sumie $14 \%$ ).

Kolejno, badani odpowiadali na pytanie dotyczące średniego czasu spędzanego w pozycji siedzącej w ciągu dnia, co charakteryzuje tabela $\mathrm{nr} 1$.

Tab. 1. Rozkład ilościowy i procentowy czasu przyjmowania pozycji siedzącej w ciagu dnia w badanych grupach.

\begin{tabular}{|c|c|c|c|c|c|c|c|c|c|c|c|c|c|}
\hline \multirow{2}{*}{\multicolumn{2}{|c|}{ pozycja siedząca }} & \multicolumn{2}{|c|}{ od $0,5 \mathrm{~h}$ do $2 \mathrm{~h}$} & \multicolumn{2}{|c|}{ od $2 \mathrm{~h}$ do $4 \mathrm{~h}$} & \multicolumn{2}{|c|}{ od $4 \mathrm{~h}$ do $6 \mathrm{~h}$} & \multicolumn{2}{|c|}{ od $6 \mathrm{~h}$ do $8 \mathrm{~h}$} & \multicolumn{2}{|c|}{ od $8 \mathrm{~h}$ do $10 \mathrm{~h}$} & \multicolumn{2}{|c|}{ 10h i więcej } \\
\hline & & $\mathbf{N}$ & $\%$ & $\mathbf{N}$ & $\%$ & $\mathbf{N}$ & $\%$ & $\mathbf{N}$ & $\%$ & $\mathbf{N}$ & $\%$ & $\mathbf{N}$ & $\%$ \\
\hline \multirow{2}{*}{ 递 } & $\begin{array}{c}\mathbf{w} \\
\text { pracy }\end{array}$ & - & - & - & - & 2 & 3,51 & 32 & 56,14 & 23 & 40,35 & - & - \\
\hline & $\begin{array}{l}\text { poza } \\
\text { pracą }\end{array}$ & 17 & 29,82 & 22 & 38,58 & 16 & 28,08 & 1 & 1,76 & 1 & 1,76 & - & - \\
\hline \multirow{2}{*}{ 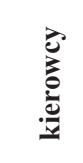 } & $\begin{array}{c}\text { w } \\
\text { pracy }\end{array}$ & - & - & - & - & 1 & 2,32 & 19 & 44,19 & 16 & 37,21 & 7 & 16,28 \\
\hline & $\begin{array}{l}\text { poza } \\
\text { pracą }\end{array}$ & 10 & 23,26 & 19 & 44,19 & 12 & 27,91 & 1 & 2,32 & 1 & 2,32 & - & - \\
\hline \multirow{2}{*}{ 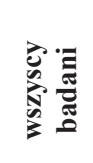 } & $\begin{array}{c}\text { w } \\
\text { pracy }\end{array}$ & & & - & - & 3 & 3 & 51 & 51 & 39 & 39 & 7 & 7 \\
\hline & $\begin{array}{l}\text { poza } \\
\text { pracą }\end{array}$ & 27 & 27 & 41 & 41 & 28 & 28 & 2 & 2 & 2 & 2 & - & - \\
\hline
\end{tabular}

Kolejne pytanie dotyczyło dotychczasowych dolegliwości bólowych dolnego odcinka kręgosłupa. Z pośród 57 pracowników biurowych, aż u 30 (52,6\%) występowały i/lub występują dolegliwości bólowe. W grupie kierowców procent tych osób był większy i wynosił $62,8 \%$.

Następnym analizowanym parametrem, był czas trwania dolegliwości. W obu grupach u znacznej liczby osób (36,66\% pracowników biurowych i 29,63\% kierowców), stwierdzono ich długotrwałe utrzymywanie się (powyżej 1 roku). Taki sam odsetek osób wśród kierowców cierpiał z tego powodu od kilku dni do tygodnia czasu. Częste utrzymywanie się do- legliwości bólowych okolicy lędźwiowo-krzyżowej w granicach od tygodnia do miesiąca stwierdzono zaś u pracowników biurowych (26,67\%).

Natężenie bólu wśród badanych wahało się od 1 do 9 w 11 stopniowej skali VAS. Najczęściej osiagało ono wartość 4 lub $6(22,8 \%)$ wśród wszystkich osób z dolegliwościami i w grupie pracowników biurowych $(26,67 \%)$, natomiast u większości kierowców oceniane było na 3 lub 5 (22,23\%).

Wpływ pozycji siedzącej (przyjmowanej u obu grup podczas pracy) na pojawienie się i nasilenie dolegliwości opisuje tabela nr 2 .

Tab. 2. Wpływ pozycji siedzącej na dolegliwości bólowe w badanych grupach - rozkład ilościowy i procentowy.

\begin{tabular}{|c|c|c|c|c|c|c|}
\hline \multirow{2}{*}{ pozycja podczas pracy } & \multicolumn{2}{|c|}{ pracownicy biurowi } & \multicolumn{2}{|c|}{ kierowcy } & \multicolumn{2}{|c|}{ wszyscy } \\
\hline & $\mathrm{N}$ & $\%$ & $\mathrm{~N}$ & $\%$ & $\mathrm{~N}$ & $\%$ \\
\hline wyzwala & 14 & 46,66 & 12 & 44,44 & 26 & 45,61 \\
\hline nasila & 8 & 26,67 & 9 & 33,33 & 17 & 29,83 \\
\hline nie ma wpływu & 8 & 26,67 & 6 & 22,23 & 14 & 24,56 \\
\hline
\end{tabular}


Czas spędzany w pozycji siedzącej, po którym ujawniał się ból wynosił od 1 do 8 godzin u pracowników biurowych i od 30 minut do 6 godzin u kierowców. U pierwszych dolegliwości bólowe pojawiały się przeważnie po 6 lub 8 godzinach, w drugiej grupie po 2 godzinach.

Dalej, ankietowani zostali zapytani w jakim stopniu dolegliwości bólowe utrudniają im wykonywanie pracy zawodowej. Dla 13,33\% pracowników biurowych i 18,52\% kierowców nie były one żadną przeszkodą podczas pracy. W stopniu lekkim utrudnienie stanowiły u 10 pracowników biurowych (33,33\%) i u 8 kierowców (29,63\%). 13 osób (43,34\%) wykonujących pracę biurową uznało, że dolegliwości bólowe dolnego odcinka kręgosłupa uniemożliwiają im pełnienie obowiązków zawodowych w stopniu średnim, a 3 osobom (10\%) w stopniu umiarkowanym. Czterem kierowcom $(14,81 \%)$ utrudniły pracę w stopniu średnim, zaś aż $10(37,04 \%)$ w stopniu umiarkowanym.

Wyniki następnych dwóch pytań zawierały informacje na temat zwolnień lekarskich wynikających z dolegliwości bó- lowych kręgosłupa lędźwiowo-krzyżowego oraz czasu ich trwania. Ze zwolnień lekarskich korzystało 30\% pracowników biurowych i 40,7\% kierowców. W obu grupach czas ich trwania w większości nie przekraczał okresu 2 tygodni $(55,6 \%$ pracownicy biurowi, 63,6\% kierowcy). Tylko jedna osoba (kierowca) przebywała na zwolnieniu powyżej 2 miesięcy.

W trzeciej części ankiety zapytano najpierw o sposób spędzania wolnego czasu. Niestety u badanych przeważały bierne formy odpoczynku (66,67\% pracownicy biurowi i 53,49\% kierowcy), wśród których zwykle wymieniane było oglądanie telewizji, przeglądanie stron internetowych, czy też czytanie książki. Pozostała cześć ankietowanych $(33,33 \%$ pracowników biurowych i 46,51\% kierowców) czynnie spędza swój czas wolny, najczęściej spacerując, pływając, jeżdżąc na rowerze lub pracując na działce.

Kolejne pytania wymagały od ankietowanych wyboru jednego, najczęściej przez nich stosowanego sposobu wykonywania danych czynności. Na początku badani zostali zapytani o sposób siedzenia (tabela nr 3.)

Tab. 3. Ilościowy i procentowy rozkład sposobów siedzenia w badanych grupach.

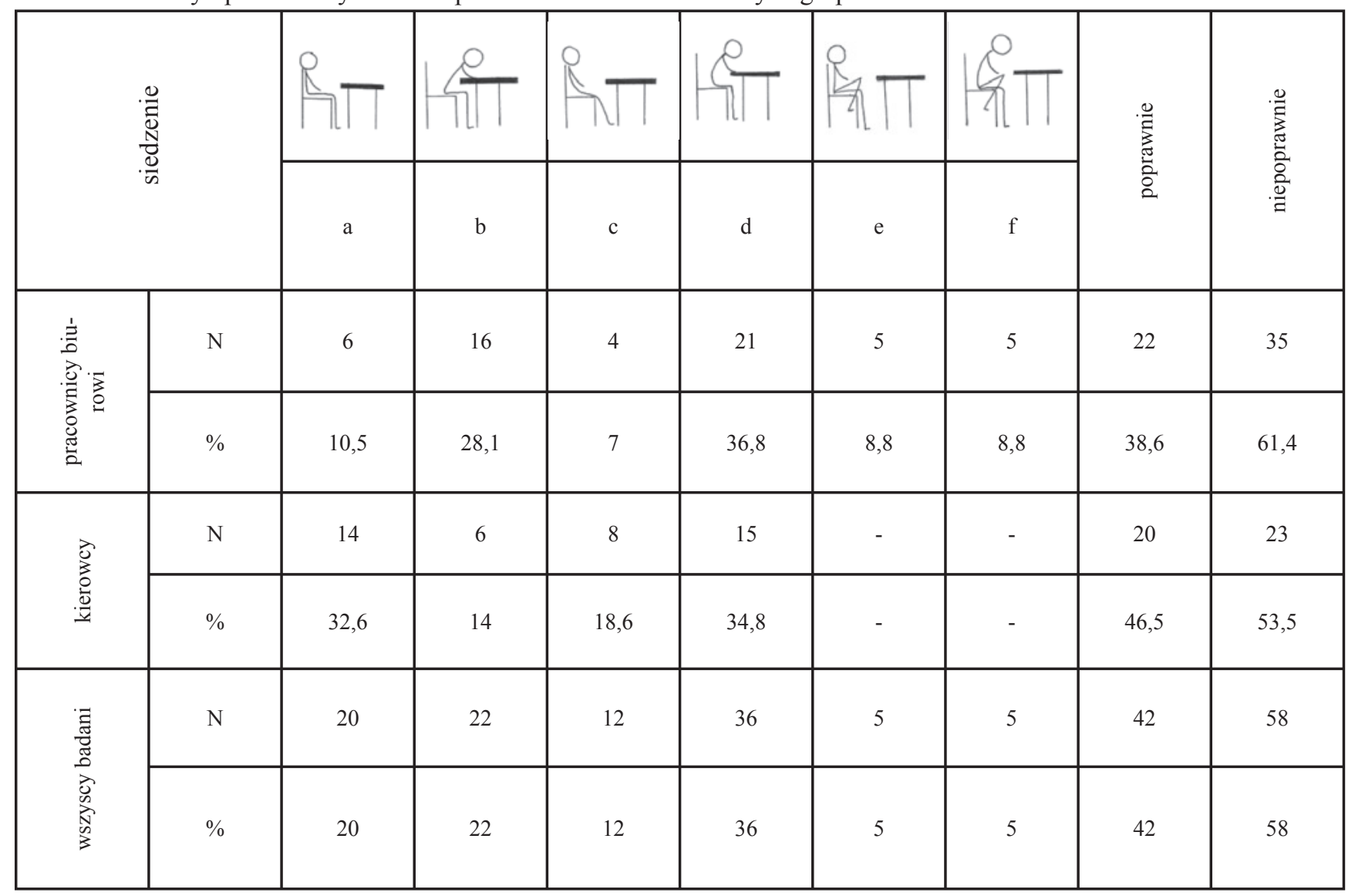


W drugiej kolejności analizowano pozycję stojąca w badanej grupie, co obrazuje tabela nr 4.

Tab. 4. Ilościowy i procentowy rozkład sposobów stania w badanych grupach.

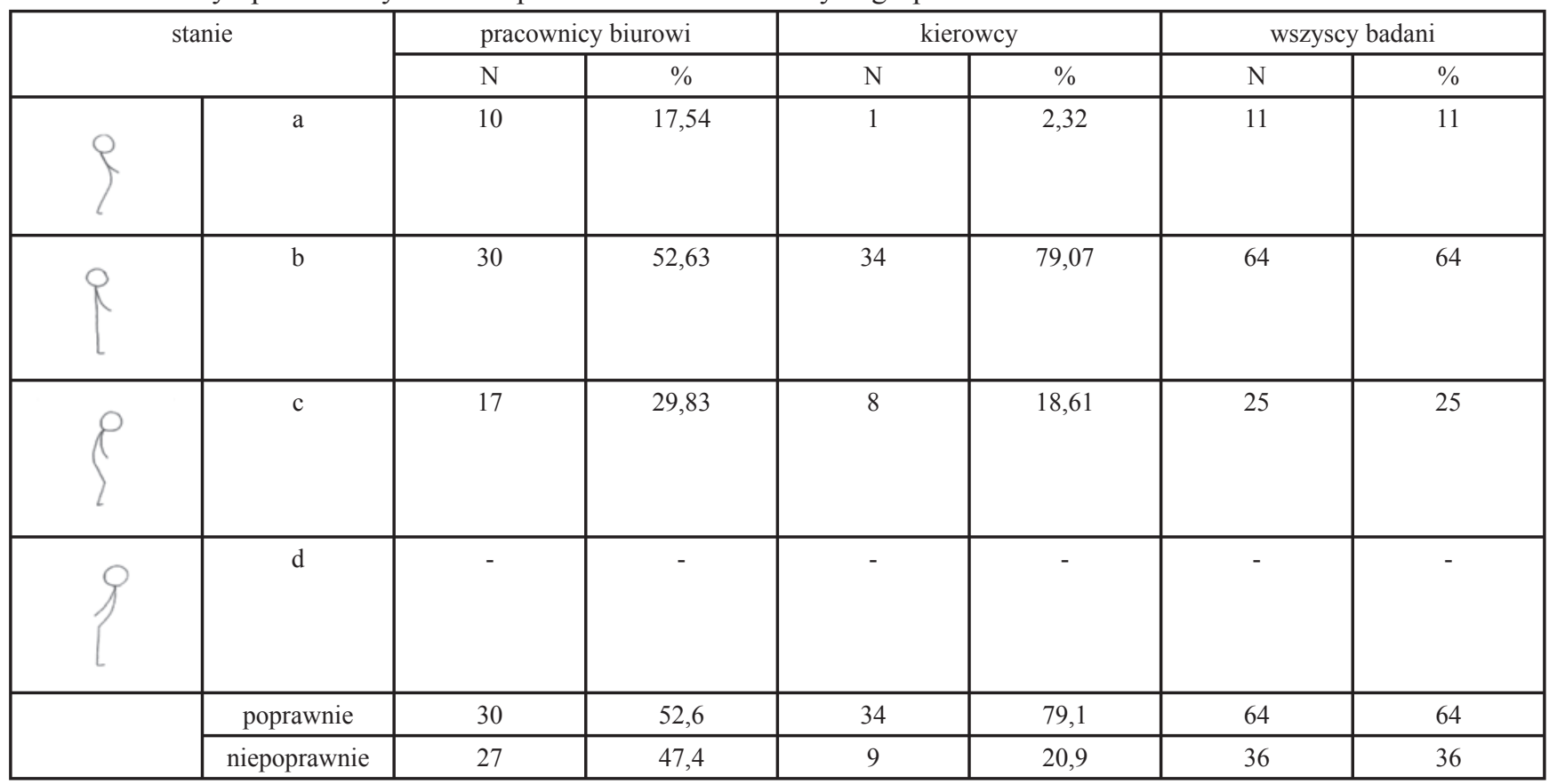

W przypadku wstawania z pozycji leżącej (np. rano z łóżka) najbardziej preferowanym $(77,19 \% \mathrm{w}$ grupie pracowników biurowych i 76,74\% kierowców) było wstawanie z leżenia tyłem, przejście do leżenia bokiem, następnie siadu $\mathrm{z}$ opuszczeniem nóg i przejściu do stania. Najrzadziej badani wstawali z leżenia tyłem, następnie leżenia bokiem, klęku podpartego, siadu klęcznego i przejścia do stania - występował on u 2 osób (2\%) pośród wszystkich badanych.

Zarówno u pracownicy biurowi i kierowcy w większości schylali się (odpowiednio 64,9\% i 58,1\%) oraz dźwigali (71,9\% i 72,1\%) w sposób prawidłowy.

Tab. 5. Ilościowy i procentowy rozkład sposobu schylania się i dźwigania w badanych grupach.

\begin{tabular}{|c|c|c|c|c|c|c|c|}
\hline \multirow{2}{*}{\multicolumn{2}{|c|}{ schylanie się }} & \multicolumn{2}{|c|}{ pracownicy biurowi } & \multicolumn{2}{|c|}{ kierowcy } & \multicolumn{2}{|c|}{ wszyscy badani } \\
\hline & & $\mathrm{N}$ & $\%$ & $\mathrm{~N}$ & $\%$ & $\mathrm{~N}$ & $\%$ \\
\hline & $\mathrm{a}$ & 20 & 35,1 & 18 & 41,9 & 38 & 38 \\
\hline & $\mathrm{b}$ & 37 & 64,9 & 25 & 58,1 & 62 & 62 \\
\hline poprawnie & & 37 & 64,9 & 25 & 58,1 & 62 & 62 \\
\hline niepoprawnie & & 20 & 35,1 & 18 & 41,9 & 38 & 38 \\
\hline \multirow{2}{*}{\multicolumn{2}{|c|}{ dźwiganie }} & \multicolumn{2}{|c|}{ pracownicy biurowi } & \multicolumn{2}{|c|}{ kierowcy } & \multicolumn{2}{|c|}{ wszyscy badani } \\
\hline & & $\mathrm{N}$ & $\%$ & $\mathrm{~N}$ & $\%$ & $\mathrm{~N}$ & $\%$ \\
\hline & $\mathrm{a}$ & 41 & 71,9 & 31 & 72,1 & 72 & 72 \\
\hline 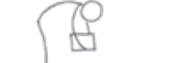 & $\mathrm{b}$ & 16 & 28,1 & 12 & 27,9 & 28 & 28 \\
\hline & poprawnie & 41 & 71,9 & 31 & 72,1 & 72 & 72 \\
\hline & niepoprawne & 16 & 28,1 & 12 & 27,9 & 28 & 28 \\
\hline
\end{tabular}


Noszenie (np. zakupów) również realizowane było najczęściej w sposób prawidłowy (71\%). Jednak to u kierowców przeważał najlepszy sposób noszenia, polegający na rozdzieleniu ciężaru na dwie ręce $(41,9 \%)$. Pracownicy biurowi w większości (40,4\%) nosili zakupy w jednej torbie, przekładając ją co jakiś czas z jednej ręki do drugiej.

Następne dwa pytania badały sposób sprzątania (zamiatania, mycia podłogi) oraz ścielenia łóżka. Na podstawie uzyskanych wyników stwierdzono, że obie te czynności wykonywane są najczęściej w sposób niewłaściwy (odpowiednio 60\% i 94\% u wszystkich badanych).

Mycie zębów, rąk w umywalce, także w obu grupach ba- danych było w większej części niepoprawne (87,7\% pracowników biurowych i 83,7\% kierowców). Prawidłowo czynność tą wykonywało $12,3 \%$ pracowników biurowych i o 4\% więcej kierowców.

Poprawny sposób ściągania i/lub zakładania skarpet (spodni), w przeciwieństwie do kilku poprzednich pytań przeważał w obu grupach $(59,6 \%$ pracowników biurowych i 53,5\% kierowców). Z prawidłowych sposobów zwykle wybierali oni sposób polegający na siadzie z prostym tułowiem na krześle i przyciągnięciem ugiętej kończyny dolnej do klatki piersiowej (31\% wszystkich badanych) niż wariant w pozycji stojącej $(26 \%)$.

Tab. 6. Procentowy rozkład oceny nawyków ruchowych w badanych grupach.

\begin{tabular}{|c|c|c|c|c|c|c|}
\hline & \multicolumn{2}{|c|}{ pracownicy biurowi } & \multicolumn{2}{|c|}{ kierowcy } & \multicolumn{2}{|c|}{ wszyscy badani } \\
\hline & poprawnie & niepoprawnie & poprawnie & niepoprawnie & poprawnie & niepoprawnie \\
\hline siedzenie & $38,6 \%$ & $61 \%$ & $46,5 \%$ & $53,5 \%$ & $42 \%$ & $58 \%$ \\
\hline schylanie się & $64,9 \%$ & $35,1 \%$ & $58,1 \%$ & $41,9 \%$ & $62 \%$ & $18 \%$ \\
\hline dźwiganie & $71,9 \%$ & $28,1 \%$ & $72,1 \%$ & $27,9 \%$ & $72 \%$ & $28 \%$ \\
\hline noszenie & $70,2 \%$ & $29,8 \%$ & $72,1 \%$ & $27,9 \%$ & $71 \%$ & $29 \%$ \\
\hline sprzątanie & $40,4 \%$ & $59,6 \%$ & $39,5 \%$ & $60,5 \%$ & $40 \%$ & $60 \%$ \\
\hline wstawanie & $78,9 \%$ & $21,1 \%$ & $79,1 \%$ & $20,9 \%$ & $79 \%$ & $21 \%$ \\
\hline ubieranie & $59,6 \%$ & $40,4 \%$ & $53,5 \%$ & $46,5 \%$ & $57 \%$ & $43 \%$ \\
\hline mycie zębów & $12,3 \%$ & $87,7 \%$ & $16,3 \%$ & $83,7 \%$ & $14 \%$ & $86 \%$ \\
\hline ścielenie łóżka & $5,3 \%$ & $94,7 \%$ & $7 \%$ & $93 \%$ & $6 \%$ & $94 \%$ \\
\hline stanie & $52,6 \%$ & $47,4 \%$ & $79,1 \%$ & $20,9 \%$ & $64 \%$ & $36 \%$ \\
\hline
\end{tabular}

Ostatnim ocenianym parametrem był wskaźnik BMI. Aż u $60 \%$ wszystkich badanych wskaźnik ten wyniósł 25 i więcej. Pośród kierowców znajdowało się znacznie więcej osób z taki BMI $(79,07 \%)$ niż w grupie pracowników biurowych
(45,61\%), z czego większą cześć stanowią osoby z BMI między 25 a 30 . Wśród wszystkich badanych nie znalazła się ani jedna osoba, której BMI przekraczałoby dolną granicę normy.

Tab. 7. Ilościowy i procentowy rozkład wskaźnika BMI w badanych grupach.

\begin{tabular}{|c|c|c|c|c|c|c|}
\hline \multirow{2}{*}{ BMI } & \multicolumn{2}{|c|}{ pracownicy biurowi } & \multicolumn{2}{|c|}{ kierowcy } & \multicolumn{2}{c|}{ wszyscy badani } \\
\cline { 2 - 7 } & $\mathrm{N}$ & $\%$ & $\mathrm{~N}$ & $\%$ & $\mathrm{~N}$ & 40 \\
\hline$<25$ & 31 & 54,39 & 9 & 20,93 & 50 & 40 \\
\hline $25-30$ & 21 & 36,84 & 29 & 67,44 & 50 & 10 \\
\hline$>30$ & 5 & 8,77 & 5 & 11,63 & 10 & 10 \\
\hline
\end{tabular}

U 80\% badanych charakteryzujących się BMI powyżej 30 występowały dolegliwości bólowe dolnego odcinka kręgosłupa. W każdej z badanych grup zjawisko to dotyczyło 4 na
5 osób. W grupach osób z BMI poniżej 25 i między 25, a 30 obecność tego problemu odnotowano u mniej więcej takiej samej części badanych (odpowiednio 55\% i 54\%).

Tab. 8. Ilościowy i procentowy rozkład dolegliwości bólowych u badanych osób z daną wartością BMI.

\begin{tabular}{|c|c|c|c|c|c|c|c|}
\hline & & \multicolumn{2}{|c|}{$<25$} & \multicolumn{2}{|c|}{$25-30$} & \multicolumn{2}{|c|}{$>30$} \\
\hline & & $\mathrm{N}$ & $\%$ & $\mathrm{~N}$ & $\%$ & $\mathrm{~N}$ & $\%$ \\
\hline \multirow{2}{*}{$\begin{array}{l}\text { pracownicy } \\
\text { biurowi }\end{array}$} & $\mathrm{z}$ bólem & 16 & 51,6 & 10 & 47,6 & 4 & 80 \\
\hline & bez bólu & 15 & 48,4 & 11 & 52,4 & 1 & 20 \\
\hline \multirow[t]{2}{*}{ kierowcy } & z bólem & 6 & 66,7 & 17 & 58,6 & 4 & 80 \\
\hline & bez bólu & 3 & 33,3 & 12 & 41,4 & 1 & 20 \\
\hline \multirow[t]{2}{*}{ wszyscy badani } & $\mathrm{z}$ bólem & 22 & 55 & 27 & 54 & 8 & 80 \\
\hline & bez bólu & 18 & 45 & 23 & 46 & 2 & 20 \\
\hline
\end{tabular}




\section{Analiza statystyczna}

W celu zweryfikowania hipotez badawczych wykonano obliczenia statystyczne przy użyciu programu komputerowego Statistica. Dla zbadania związku między zebranymi danymi użyto testu $\chi 2$ Pearsona.

Sprawdzono zależności pomiędzy odczuwaniem dolegliwości bólowych a sposobem schylania się, siedzenia, podnoszenia, noszenia, sprzątania, wstawania z łóżka, rozbierania się, mycia zębów, ścieleniu łóżka i stania. Zależność istotną statystycznie zaobserwowano tylko pomiędzy odczuwaniem dolegliwości bólowych a sposobem noszenia ciężkich rzeczy.

Analizując noszenie zakupów w grupie b (noszenie zakupów w jednej ręce ale przekładanie ciężaru do drugiej reki) zaobserwowano, iż dolegliwości bólowe występują prawie dwa razy częściej niż w a (noszenie zakupów tylko w jednej ręce) $(69,4 / 37,9=1,8)$, ale $\mathrm{z}$ podobną częstotliwością jak w c (noszenie ciężaru równomiernie rozłożonego na obie ręce).
Tab. 9. Zależność pomiędzy odczuwaniem dolegliwości bólowych a noszeniem ciężkich rzeczy.

\begin{tabular}{|c|c|c|c|}
\hline \multirow{2}{*}{ statystyka } & \multicolumn{3}{|c|}{$\begin{array}{c}\text { Statystyka: noszenie(3) x ból(2) (Arkusz62 } \\
\text { w postawa ciała) }\end{array}$} \\
\cline { 2 - 4 } & Chi-kwadr. & $\mathrm{df}$ & $\mathrm{p}$ \\
\hline $\begin{array}{c}\text { Chi^2 Pear- } \\
\text { sona }\end{array}$ & 6,705528 & $\mathrm{df}=2$ & $\mathrm{p}=, 03499$ \\
\hline $\mathrm{Chi}^{\wedge} 2 \mathrm{NW}$ & 6,740211 & $\mathrm{df}=2$ & $\mathrm{p}=, 03439$ \\
\hline
\end{tabular}

Sprawdzono również zależność pomiędzy natężeniem dolegliwości bólowych a postawą ciała. Różnice te sprawdzono za pomocą testu ANOVA rang Kruskala-Wallisa (gdy więcej niż dwie grupy) oraz testem Kołmogorowa-Smirnowa $\mathrm{i}$ testem Manna-Whitneya (dla dwóch grup). Zależność istotna statystycznie zaobserwowano tylko u osób deklarujących noszenie ciężkich rzeczy w jednej ręce z przekładaniem ich od czasu do czasu do drugiej ręki.

Tab. 10. Zależność pomiędzy postawą ciała a noszeniem ciężkich rzeczy (test Kołmogorowa-Smirnowa)

\begin{tabular}{|c|c|c|c|c|c|c|c|c|}
\hline \multirow{2}{*}{ Zmienna } & \multicolumn{8}{|c|}{$\begin{array}{c}\text { Test Kołmogorowa-Smirnowa (Arkusz } 62 \mathrm{w} \text { postawa ciała) } \\
\text { Względem zmiennej: noszenie } \\
\text { Zaznaczone wyniki są istotne z } \mathrm{p}<, 05000\end{array}$} \\
\hline & $\begin{array}{l}\text { Maks.uj. } \\
\text { Różnica }\end{array}$ & $\begin{array}{l}\text { Maks.dod } \\
\text { Różnica }\end{array}$ & $\mathrm{p}$ & $\begin{array}{c}\text { Średnia } \\
\text { b }\end{array}$ & $\begin{array}{c}\text { Średnia } \\
\mathrm{a}\end{array}$ & $\begin{array}{c}\text { Odch.std } \\
\text { b }\end{array}$ & $\begin{array}{c}\text { Odch.std } \\
\text { a }\end{array}$ & $\begin{array}{c}\mathrm{N} \text { ważn. } \\
\mathrm{b}\end{array}$ \\
\hline $\begin{array}{l}\text { natężenie } \\
\text { bólu }\end{array}$ & $\begin{array}{c}- \\
0,034483\end{array}$ & 0,349617 & $\mathrm{p}<.05$ & $\begin{array}{c}2,86111 \\
1\end{array}$ & $\begin{array}{c}1,72413 \\
8\end{array}$ & $\begin{array}{c}2,19288 \\
2\end{array}$ & $\begin{array}{c}2,51987 \\
2\end{array}$ & 36 \\
\hline
\end{tabular}

Tab. 11. Zależność pomiędzy postawą ciała a noszeniem ciężkich rzeczy (test Manna-Whitneya).

\begin{tabular}{|c|c|c|c|c|c|c|c|c|}
\hline \multirow[t]{2}{*}{ Zmienna } & \multicolumn{8}{|c|}{$\begin{array}{c}\text { Test U Manna-Whitneya (Arkusz62 w postawa ciała) } \\
\text { Względem zmiennej: noszenie } \\
\text { Zaznaczone wyniki są istotne z } \mathrm{p}<, 05000\end{array}$} \\
\hline & $\begin{array}{c}\text { Sum.rang } \\
\text { b }\end{array}$ & $\begin{array}{c}\text { Sum.rang } \\
\mathrm{a}\end{array}$ & U & Z & $\mathrm{p}$ & $\begin{array}{c}\mathrm{Z} \\
\text { popraw. }\end{array}$ & $\mathrm{p}$ & $\begin{array}{c}\mathrm{N} \text { ważn. } \\
\mathrm{b}\end{array}$ \\
\hline natężenie bólu & 1332,500 & 812,5000 & $\begin{array}{c}377,500 \\
0\end{array}$ & $\begin{array}{c}1,90033 \\
8\end{array}$ & $\begin{array}{c}0,05739 \\
0\end{array}$ & $\begin{array}{c}1,99879 \\
3\end{array}$ & $\begin{array}{c}0,04563 \\
2\end{array}$ & 36 \\
\hline
\end{tabular}

Sprawdzono również zależność pomiędzy wskaźnikiem BMI a występowaniem dolegliwości bólowych. Osoby de- klarujące występowanie dolegliwości bólowych miały wyższe średnie BMI ale nie była to różnica istotna statystycznie.

Tab. 12. Zależność pomiędzy BMI a występowaniem dolegliwości bólowych.

\begin{tabular}{|c|c|c|c|c|c|c|c|c|c|}
\hline & \multicolumn{9}{|c|}{ Testy t; Grupująca: ból (Arkusz62 w postawa ciała) } \\
Grupa 1: nie \\
Grupa 2 tak
\end{tabular}

\section{Dyskusja}

Dolegliwości bólowe okolicy lędźwiowo-krzyżowej są istotnym problemem, dotykającym znaczną część społeczeństw na całym świecie. Zarówno ze względów medycznych, społecznych i ekonomicznych coraz częściej próbuje się określić te grupy osób, które w szczególności są narażone na ich wystapienie. Nie bez znaczenia jest tutaj charakter wykonywanej pracy zawodowej. [1, 2, 16]
Obecnie dużo miejsca na łamach czasopism naukowych poświęca się dywagacjom na temat związku pozycji siedzącej, powodującej znaczne obciążenie kręgosłupa z dolegliwościami bólowymi jego dolnego odcinka. Siedzący tryb życia, wymuszony charakterem pracy zawodowej był do tej pory uważany za jeden $\mathrm{z}$ głównych czynników ryzyka tych dolegliwości, jednak ostatnie doniesienia nie potwierdzaja powyżej przedstawionej zależności. [17, 18, 19] Lis i współ. [18] po dokonaniu przeglądu 24 wybranych publikacji (od 
1990 do 2004 roku) stwierdzili, że samo siedzenie nie wykazuje związku z występowaniem bólu krzyża. Zależność ta istnieje dopiero $\mathrm{w}$ połączeniu $\mathrm{z}$ innymi czynnikami takimi jak drgania czy nieprawidłowe pozycje. Chen i współ. [17] wykonując podobną analizę (artykuły od 1998 do 2006) również doszli do wniosku, że nie ma dostatecznych dowodów na potwierdzenie związku siedzącego trybu życia z występowaniem dolegliwości bólowych dolnego odcinka kręgosłupa.

Dyskusja co do siedzącego trybu życia jako czynnika ryzyka bólów odcinka lędźwiowo-krzyżowego kręgosłupa pozostaje nadal nierozstrzygnięta. Większość autorów publikacji jest jednak zgodna co do faktu zwiększonego występowania tego zjawiska u niektórych grup zawodowych, wykonujących pracę w pozycji siedzącej. $[17,19,18]$

Badania własne przeprowadzono na grupie 100 osób, wśród których znalazło się 57 pracowników biurowych i 43 kierowców. U ponad połowy wszystkich badanych (57\%) odnotowano epizody bólów dolnego odcinka kręgosłupa, przy czym występowały one częściej w grupie kierowców $(62,8 \%)$. Fakt ten można wytłumaczyć tym, że w znacznej części osoby $\mathrm{z}$ tej grupy spędzały więcej czasu w pracy w pozycji siedzącej oraz oddziaływaniem na nie wibracji ogólnej. Mimo, że w ostatnich latach w produkcji samochodów stosuje się innowacyjne rozwiązania mające na celu zmniejszenie niekorzystnego wpływu drgań, to z uwagi na dużą liczbę osób w tej grupie z długoletnim stażem pracy (powyżej 10 lat), można uznać ten czynnik za istotny.

Odmienne rezultaty od powyższych otrzymał Sosin i współ. [8] badając grupę 100 pracowników sektora biurowego. Aż 91\% osób odpowiedziało pozytywnie na pytanie dotyczące dotychczasowego występowania bólu tego regionu. Jednakże badania przeprowadzone przez Spyropoulosa i współ. [20] na większej próbie (648 pracowników biurowych), określiły rozpowszechnienie bólów krzyża na poziomie $61,6 \%$, co jest wynikiem bardziej zbliżonym do danych uzyskanych z badań własnych.

Kierowców uważa się za grupę szczególnie podatną na rozwój dolegliwości bólowych dolnego odcinka kręgosłupa. [21, 17, 18. 22, 16, 23] Według Siedleckiej [16] są one najczęstszym powodem skarg związanych z układem mięśniowo-szkieletowym w tej grupie zawodowej. Dziak [10] podaje, że w przypadku osób spędzających połowę czasu pracy na prowadzeniu pojazdów ryzyko choroby zwyrodnieniowej krążka międzykręgowego jest trzykrotnie większe. Szeto i Lam [23] w swoim artykule stwierdzili, że u kierowców (samochodów ciężarowych i autobusów) w porównaniu z grupą osób wykonujących pracę siedzącą bóle kręgosłupa lędźwiowo-krzyżowego występują znacznie częściej. Wyniki otrzymane z badań własnych pozwalają się zgodzić z powyższym stanowiskiem. Częste występowanie tego problemu wśród tej grupy zawodowej potwierdzają także inne doniesienia. Odnosząc się do okresu 12 miesięcy, poszczególni autorzy otrzymali wyniki wskazujące na występowanie dolegliwości bólowych dolnego odcinka kręgosłupa na poziomie $45,4 \%$ u kierowców autobusów, oraz 20,5\% u taksówkarzy. [21, 22]

W przeprowadzonych badaniach własnych większość badanych $(57,89 \%)$ uznała długotrwałe utrzymywanie pozycji siedzącej podczas pracy za główną przyczyną występowania dolegliwości bólowych okolicy lędźwiowo-krzyżowej. W większości przypadków pozycja ta wyzwalała te dolegliwości po około 2 godzinach u kierowców, a po 6 lub 8 u pracowników biurowych. Podobne stwierdzenia znaleźć można w innych publikacjach. [24, 23] Na drugim miejscu znalazł się brak odpowiedniej aktywności fizycznej. Powyższe stwierdzenia mają swoje odbicie w podanych przez ankietowanych informacjach odnośnie spędzania wolnego czasu. W obu grupach dominowały biernie formy wypoczynku. Niestety tendencja ta dotyczy w znacznej mierze dzisiejszych społeczeństw. [25]

Za kolejny czynnik mogący prowokować występowanie dolegliwości bólowych kręgosłupa uważa się nieprawidłowe nawyki ruchowe. [10, 26, 18, 14, 15] Niewłaściwe wykonywanie zadań ruchowych prowadzi początkowo do dysbalansu mięśniowego, a następnie do powstawania przeciążeń, które z kolei wyzwalają dolegliwości bólowe. [14, 15] Wydawać by się mogło, że wielokrotnie powtarzane w ciągu dnia czynności takie jak dźwiganie, schylanie się, siedzenie, stanie $\mathrm{i}$ in. będą wykonywane w sposób poprawny, czyli podając za Stodolnym $[14,15]$, z użyciem jak najmniejszej liczby mięśni, najmniejszej potrzebnej siły oraz z zachowaniem maksymalnego bezpieczeństwa tkanek. Niestety, nie zawsze można to potwierdzić.

Rudzińska i współ. [12] oceniała sposób wykonywania trzech czynności życia codziennego przez osoby bez dolegliwości dolnego odcinka kręgosłupa. Badani byli obserwowani podczas wykonywania zmiany pozycji z leżenia tyłem (na kozetce) do stania, przyjmowania pozycji siedzącej na krześle oraz podnoszenia ciężaru z podłogi. W większości przypadków wykonanie w/w zadań ruchowych było nieprawidłowe. Najlepiej osoby radziły sobie z podnoszeniem ciężaru z podłogi (46,42\%), gorzej z przyjęciem odpowiedniej pozycji siedzącej $(39,63 \%)$ oraz z przejściem z leżenia tyłem do stania $(23,77 \%)$.

Wyniki badań własnych pozwalają częściowo zgodzić się z powyżej przedstawionymi. Zarówno pracownicy biurowi jak i kierowcy wybierali właściwy sposób dźwigania, jednak ich odsetek był znacznie większy (odpowiednio 71,9\% i 72,1\%). W przeciwieństwie do otrzymanych przez Rudzińską i współ. [12] danych nie odnotowano większych problemów z wstawaniem z pozycji leżącej (aż 79\% wszystkich prawidłowych). Natomiast stopień poprawności przyjmowanej pozycji siedzącej był zbliżony (42\% wszystkich badanych).

Przyczyn występujących różnic można się doszukiwać w fakcie występowania dolegliwości bólowych wśród ankietowanych, przeciwnie do tych, objętych badaniami przez Rudzińską. [12] Przypuszczalnie, osoby, które doświadczyły bólów okolicy lędźwiowo-krzyżowej mogą posiadać wyższą świadomość zdrowotną. Prawdopodobnie zostały one poinstruowane (w przebiegu leczenia) odnośnie sposobów wykonywania niektórych zadań ruchowych szczególnie tych w wysokim stopniu narażających na wystąpienie bólu. Osoby wolne od tego rodzaju dolegliwości, które znalazły się razem z nimi w badanych grupach, poprzez wymianę poglądów i obserwacje mogły również zmienić sposób wykonywania wybranych czynności. 
Niepoprawne siedzenie, stwierdzone w przypadku 58\% wszystkich badanych w wyniku przeprowadzonych własnych badań, dopiero po pewnym okresie czasu może wyzwolić ból. Możliwe jest zatem, że na co dzień nie przywiązują oni do niej, aż tak dużej uwagi. Innym możliwym wytłumaczeniem może być brak i/lub niedostateczne dopasowanie pod względem ergonomicznym stanowiska pracy. Przeprowadzona ankieta nie zawierała pytania na ten temat, jednak na podstawie badań innych autorów można uznać to zjawisko za dość częste. [21, 22, 8, 23]

Siedzący tryb życia sprzyja nadwadze i otyłości. Obecnie podobnie jak w przypadku długotrwałego utrzymywania pozycji siedzącej nie ma jednoznacznego stanowiska łączącego wysoki wskaźnik BMI (25 i powyżej), będącego kryterium rozpoznania tych stanów, z problemem bólów odcinka lędźwiowo-krzyżowego. [27, 28, 29] Gasik i Styczyński [28] przeprowadzali badania na grupie pacjentów hospitalizowanych z powodu zespołów bólowych kręgosłupa lędźwiowego. BMI w granicach 25-29,9 dotyczył 23\% chorych, a wynoszący 30 i więcej posiadało $69 \%$.

W przeprowadzonych badaniach własnych w grupie osób z BMI wynoszącym 30 i więcej, aż 4 na 5 osób cierpiało z powodu dolegliwości bólowych dolnego odcinka kręgosłupa. Natomiast u osób z nadwagą i prawidłowym BMI występowanie problemu odnotowano na podobnym poziomie (odpowiednio 54\% i 55\%).

Praktycznymi implikacjami wynikającymi z niniejszej pracy jest konieczność zwrócenia uwagi na szerokie zastosowanie zasad profilaktyki dolegliwości bólowych kręgosłupa podczas czynności dnia codziennego, które to zadanie, w polskim systemie opieki zdrowotnej, spoczywa w głównej mierze na fizjoterapeutach.

\section{Wnioski}

1.Dolegliwości bólowe dolnego odcinka kręgosłupa występowały częściej w grupie badanych kierowców.

2. U badanych osób z wysokim wskaźnikiem BMI (25 i więcej) występowały dolegliwości bólowe dolnego odcinka kręgosłupa, przy czym w grupie osób charakteryzujących się BMI równym lub większym 30, dolegliwości te były częstsze.

3. Spośród badanych nawyków ruchowych, ścielenie łóżka i mycie zębów charakteryzowały się najczęstszym występowaniem niepoprawności w ich wykonaniu u osób badanych.

\section{Bibliografia}

1. Depa A, Drużbicki M. Ocena częstości występowania zespołów bólowych lędźwiowego odcinka kręgosłupa w zależności od charakteru wykonywanej pracy. Przegląd Medyczny Uniwersytetu Rzeszowskiego 2008;1:34-41.

2. Holenderskie Królewskie Towarzystwo Fizjoterapii. Zalecenia stosowania fizjoterapii u pacjentów z bólami krzyża. Rehabilitacja Medyczna 2004;8:6-27.

3. Koes BW, van Tulder MW, Thomas S. Diagnosis and treatment of low back pain. BMJ 2006;332:1430-1434.

4. Kuryliszyn-Moskal A. Terapia zespołów bólowych kręgosłupa lędźwiowo-krzyżowego - strategie postępowania.
Reumatologia 2009;47,6:368-371.

5. Kwolek A, Korab D, Majka M. Rehabilitacja w zespołach bólowych dolnego odcinka kręgosłupa - zasady postępowania. Postępy Rehabilitacji 2004;18,3:27-31.

6. Marciniak W, Szulc A. Wikora Degi ortopedia i rehabilitacja. Warszawa: Wydawnictwo Lekarskie PZWL; 2003.

7. Mikołajczyk A, Kupcewicz E. Dolegliwości bólowe pleców wśród pacjentów podstawowej opieki zdrowotnej. Kwartalnik Ortopedyczny 2010;1:86-93.

8. Sosin P, Żłobiński W, Bac A. Zespoły bólowe kręgosłupa szyjnego i lędźwiowego u pracowników sektora biurowego. Annales Universitatis Mariae Curie-Skłodowska LublinPolonia 2007;62(18),7(D):402-405.

9. Bjork van Dijken Ch, Fjellman-Wiklund A, Hildingsson Ch. Low back pain, lifestyle factors and physical activity: a population-based study. Journal of Rehabilitation Medicine 2008;40:864-869.

10. Dziak A. Bolesny krzyż. Kraków: Medicina Sportiva; 2003.

11. Gałuszka G, Gałuszka R. Rola prewencji wtórnej w zapobieganiu nawrotom dolegliwości bólowych lędźwiowokrzyżowego odcinka kręgosłupa wynikających z zespołu przeciążeniowego. Kwartalnik Ortopedyczny 2005;3:206-208.

12. Rudzińska A, Nowotny-Czupryna O, Knapik H. Ocena sposobu wykonywania wybranych czynności dnia codziennego w świetle pierwotnej profilaktyki dolegliwości bólowych dolnego odcinka kręgosłupa. Fizjoterapia Polska 2001;1,4:381-384.

13. Kiwerski J. Rehabilitacja medyczna. Warszawa, Wydawnictwo Lekarskie PZWL, 2005

14. Stodolny J. Choroba przeciążeniowa kręgosłupa epidemia naszych czasów. Kielce, Wydawnictwo ZL Natura, 2000 .

15. Stodolny J. Jak chronić swój kręgosłup? Kielce, Wydawnictwo ZL Natura, 1997.

16. Siedlecka J. Wybrane problemy zdrowotne związane z pracą kierowców pojazdów komunikacji miejskiej. Medycyna Pracy 2006;57(1):47-52.

17. Chen S.-M, Liu M.-F, Cook J, Bass S, Lo S.K. Sedentary lifestyle as a risk factor for low back pain: a systematic review. International Archives of Occupational Environmental Health 2009;82:797-806.

18. Lis AM, Black KM, Korn H, Nordin M. Association between sitting and occupational LBP. European Spine Journal 2007;16:283-298.

19. Hartvigsen J, Leboeuf - Yde Ch, Lings S, Corder EH. Is sitting-while-at-work associated with low back pain? A systematic, critical literature review. Scandinavian Journal of Public Health 2000;28:230-239.

20. Spyropoulos P, Papathanasiou G, Georgoudis G, Chronopoulos E, Koutis H, Koumoutsou F. Prevalence of Low Back Pain in Greek Public Office Workers. Pain Physician 2007; 10:651-660.

21. Alperovitch-Najenson D, Santo Y, Masharawi Y, KatzLeurer M, Ushvaev D, Kalichman L. Low Back Pain among Professional Bus Drivers: Ergonomic and OccupationalPsychosocial Risk Factors. Israel Medical Association Journal 2010;12,1:26-31. 
22. Miyamoto M, Konno S, Gembun Y, Liu X, Minami K, Ito H. Epidemiological Study of Low Back Pain and Occupational Risk Factors among Taxi Drivers. Industrial Health 2008;46:112-117.

23. Szeto GPY, Lam P. Work-related Musculoskeletal Disorders in Urban Bus Drivers of Hong Kong. Journal Occupational Rehabilitation 2007;17:181-198.

24. Lisiński P, Małgowska M. Jakość życia a zespół bólowy kręgosłupa na tle przeciążeniowym. Chirurgia Narządów Ruchu i Ortopedia Polska 2005;70,5:361-365.

25. Drygas W. Czy siedzący tryb życia nadal stanowi zagrożenie dla zdrowia społeczeństwa polskiego? Medycyna Sportowa 2006;22,2(6):111-116.

26. Lewit K. Terapia manualna w rehabilitacji chorób narządu ruchu. Kielce, Wydawnictwo ZL Natura, 2001
27. Białachowski JT, Stryła W. Analiza wybranych cech antropometrycznych i rodzaju pracy zawodowej u chorych z przepukliną jądra miażdżystego części lędźwiowej kręgosłupa. Postępy Rehabilitacji 2002;16,1:33-41.

28. Gasik J, Styczyński T. Niektóre cechy szczególne przebiegu klinicznego zespołów bólowo-korzeniowych wywołanych dyskopatią lędźwiową u chorych z otyłością. Reumatologia 2005;43,5:252-256.

29. Shiri R, Solovleva S, Husgafvel-Purslainen K, Taimela S, Saarikoski LA, Huupponen R, Viikari J, Raitakari OT, Viikari-Juntura E. The Association between Obesity and the Prevalence of Low Back Pain in Young Adults. American Journal of Epidemiology 2008;167,9:1110-1119. 